\title{
Effect of Cultural Differences in Reaction of Students to Ambiguous Art Stimulus
}

\author{
Petra Potmesilova, Petra Sobkova, Marcela Fojtikova Roubalova \\ Department of Christian Education, Sts. Cyril and Methodius Faculty of Theology, Palacky University Olomouc, \\ Olomouc, Czech Republic \\ Email: petra.potmesilova@upol.cz, petra.sobkova@gmail.com, roubalova.marcela@gmail.com
}

Received October 2014

\begin{abstract}
Reconstruction is one of the basic methods used in art therapy and the artphiletic approach to work with a client. The method of Reconstruction can be used in practice not only for development of imagination, but also as a means of obtaining information about the ways clients react to ambiguous stimuli. The present article compares reactions of students of Palacký University in Olomouc and students of Sichuan University at Chengdu to an ambiguous stimulus using the reconstruction method.
\end{abstract}

\section{Keywords}

Ambiguous Stimulus, Art Therapy, Artphiletic Approach, University Student, Czech Republic, People's Republic of China

\section{Introduction}

Individuals often come across ambiguous stimuli in everyday life as well as in the process of education and upbringing. Ambiguous stimuli create situations which may be classified as problems. The individual then tries or needs to resolve the encountered problem. The way people approach an ambiguous stimulus and therefore problem solving depends on a couple of basic factors. Plháková [1] defines these factors as problem understanding, previous learning, professional knowledge and creativeness. This article will further deal in detail with one of these factors, namely creativeness.

Carter and Russell [2] define creativeness as a mental process leading towards solution, ideas or products that are new. Smékal [3] characterises creativeness as psychological activity involving an untraditional approach to objects, an original approach, inventiveness and use of unusual associations. Žák [4] defines creativeness as the sum of process, attitude and ability. Creativeness as a process mainly means continual mental activity generating a solution with a space for improvisation. Attitude is mainly willingness to accept change, play with ideas and be flexible. Ability involves imagination and thinking out new things and also generation of ideas on the basis of combinations, changes or recapitulations of already existing ideas.

Creativeness thus makes it possible to approach task solving in a brand new way and yet to create correct solutions of the tasks. Tolerance for ambiguity is innate to a large extent but can also be developed. The present study focuses on the category of university students and regarding the development stages of human life and their 
reflection in the psychosocial image of the personality perception and creativeness may be expected to be grounded in the childhood. Schum et al. [5] published a comparative study in which they showed a difference in strategies of these two age categories, at the same time pointing out importance of their development in the school age.

One of the options of development of creativeness is use of art therapy in the process of education and upbringing. Art therapy is usually defined as expressive therapy using methods and techniques of visual art in work with the client. Art therapy uses visual art as a means of self-expression in communication, rather than striving for aesthetically satisfactory end products assessed on the basis of external benchmarks [6]. Art therapy leads to desirable changes of the personality and its overall development. An appropriately chosen method of art therapy can also lead to development of a particular ability.

In the context of use of elements of art therapy in the process of education and upbringing the term artphiletic approach has been introduced in the Czech Republic. The spiritual father of this term is Jan Slavík [7]. Artphiletic approach is closely linked to art therapy as it uses similar procedures as art therapy, transforming them to upbringing. The purpose of artphiletic approach is not therapy like in the case of art therapy but upbringing and contribution to self-recognition, development of positive personality features and the personality as a whole. Frequent use of the arthpiletic approach to education is currently part of prevention of social and other pathologies.

In relation to the above, one professional article needs to be mentioned, in which Albert [8] deals with the potential connection of art therapeutic procedures with implementation of objectives of education and upbringing. The author thus describes what the Czechs call artphiletic approach. The greatest inspiration may be drawn from the parts of the articles in which the author describes lesson planning and student reflections. A rather different approach to use of art therapeutic elements or procedures at school is adopted by Nelson [9], who emphasises the atmosphere of the environment in which these elements are used. According to Nelson it is not enough to rely solely on acceptance of elements of art therapy by pupils or students, but also the atmosphere or climate of the school must be considered. About the importance of climate in the education process writes for example Pospíšilová [10].

The method of reconstruction is one of the art therapeutic methods helping develop creativeness of individuals and thus their ability to react to ambiguous stimuli. In the context of this method the client receives part of a selected artefact, i.e. an ambiguous stimulus, and is asked to complete the artefact, on the basis of his or her feelings, ideas, i.e. to react to the ambiguous stimulus. On the basis of evaluation of this reaction it is possible to obtain information about how the individual is able to work with tension created by an ambiguous stimulus (see below).

\section{Methodology}

There are several diagnostic instruments measuring the level of imagination, including the Torrance figural test of creative thinking. This test is used for evaluation of imagination, creativeness and original ways of solution of art tasks. The test is based on the theory of gestalt psychology. The basic idea following from gestalt psychology can be defined as follows: Incomplete figures create tension in the individual, leading to the effort to complete the figure in the simplest possible way. For an original response this tension leading to the simplest solution must be controlled to extend the time of seeking.

In the context of the Torrance figural test of creative thinking the individual receives a creative tasks in which the most common and at first sight clear solution is "suggested". The tasks require thinking of an original solution of the task, i.e. to overcome the tension leading to the simplest solution. The individual is free to accept the "suggested" solution and make the task unambiguous. Or he or she can put the offered solution aside and seek another, hidden meaning, i.e. may accept the fact that the task processing may be multivalent.

This basic principle on which the Torrance figural test of creative thinking is based corresponds to one of the principles of the art therapeutic method of Reconstruction. In practice you can come across three types of reactions:

- Rejection of the first idea and a search for another, original solution,

- Acceptance of the first idea,

- Fear of non-fulfilment of the task, fear of arriving at an "incorrect" solution.

On the basis of this test and in harmony with the method of Reconstruction a specific task was created for this purpose allowing for studying human reactions to ambiguous stimulus. 
The authors of the present article have professionally studied reactions to ambiguous stimuli for nine years and periodically published results in professional journals or presented them at local and international conferences [11] [12]. Since 2010 the authors have regularly given lectures on art therapy at Sichuan Normal University at Chengdu (PRC). On the basis of these facts the authors have decided to carry out the research presented here.

\subsection{Research}

Qualitative and quantitative methodology was chosen for the research implementation. On the basis of practical experience and the above-mentioned theory, the following research question was formulated:

Research question: Are there culture-based differences in perception of an ambiguous stimulus? If yes, what are they?

\subsection{Data Collection Methods}

The principal data collection method chosen was analysis of activity results. This method was supported by two more approaches:

- Visible and nonaligned observation,

- Semi-structured interview.

Every respondent received the following picture, representing a section, or 1/4 of a larger picture (Figure 1):

In addition to this picture, in the following text referred to as the original motif or ambiguous stimulus, every respondent received an empty white paper sheet (format A4), colour pencils in 24 different colours and glue.

After handing out the artist aids the following instruction was given:

"You have received part of a picture. First of all look at it carefully, you can also turn it. As soon as you think the picture reminds you of anything try to complete it. Glue the part of the picture to the white paper you have received. You can intervene with the picture in any way you like. You can use any of the artist aids you have received.

In the Czech Republic the instruction was given in the Czech language. In China the instruction was given in English and translated into Chinese.

The working respondents were observed for handling the picture and speed of solution. The time for the work was adapted to the respondent group characteristics and ranged from 10 minutes to half an hour. The work on the picture was followed by the semi-structured interview in the context of which the following questions were asked:

1. Is your work the result of an instant idea, did you know immediately what you would do?

2. Was this idea the only one or did you have more ideas about what to do?

3. If you had more ideas why did you choose this particular solution?

Further questions were asked on the basis of each particular case and situation developing from the previous conversation. At the end of the session the respondents were shown the whole picture from which the section was cut out for them to work with. After showing the whole picture a short discussion usually evolved from which further valuable information could be drawn.
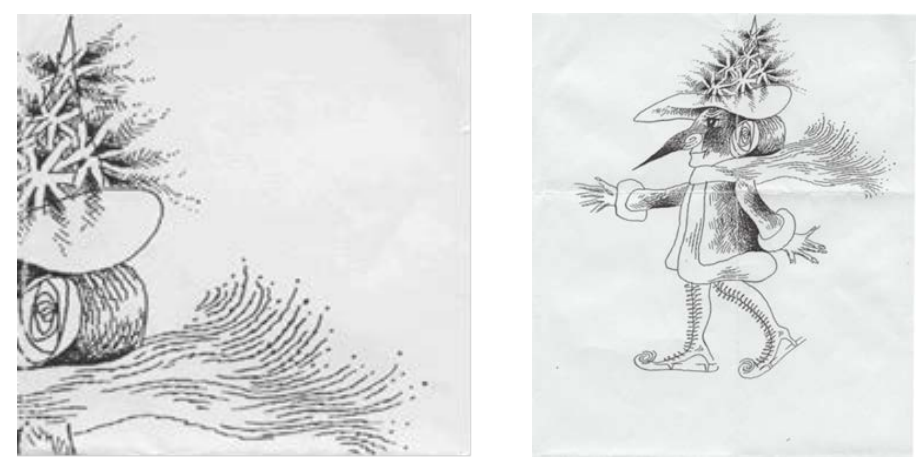

Figure 1. Selected part of the drawing—Not unambiguously led inducement and original drawing. 


\subsection{Research Population}

By the end of June 2014, 600 respondents from the Czech Republic and 120 respondents from China took part in the research. All respondents were above 18 years of age and more than 3/4 of them were women. In the Czech Republic the respondents included students of special pedagogy, social pedagogy and lifelong education with a focus on art therapy and teachers working in special schools. In China the respondents included students of psychology and teaching at nursery schools and teachers working in special schools. These respondents came from Sichuan Province.

Respondents from the Czech Republic were selected at random-addressed in class or at a training course. Respondents from China were also selected at random-20 respondents were selected from among the volunteers attending each of our lectures.

\section{Processing Methods and Data Analysis}

Data processing was based on the method of systematic storage and fixation of qualitative data. Pictures created by the respondents were stored by date and collection point for further analysis. Notes were taken from the observations and interviews, dated, provided with information about the place of the data collection and attached to the individual pictures.

Analysis of the data obtained from the first, the second and the third research session was performed first by the method of pattern identification and then by simple listing. Qualitative methods were complemented with descriptive statistics, which is a quantitative method. The method of pattern identification was used to find repeating themes-categories-which, if found, were recorded. New pictures were then included under these defined categories. This method was followed by the simple listing method by means of which we tried to find how often each category occurred and what its proportion to the other categories was. For the sake of increased transparency the qualitative methods were complemented with descriptive statistics which organised numbers and percentages relating to the individual categories into tables and diagrams. The simple listing and descriptive statistic methods thus became a significant aid in interpretation of the qualitative data.

\subsection{Presentation of Research Results}

The presented technique is an example of the art therapeutic method of Reconstruction, the essence of which is that the client receives part of a selected artefact and his or her task is to creatively complete the artefact on the basis of his or her feelings and ideas.

As mentioned above, the data analysis was based on the results of observations, interviews and the work on the artefact itself. Originality and elaboration were evaluated for each created artefact. The Torrance figural test of creative thinking characterises originality as a non-standard, less common, but still adequate reaction to ambiguous stimulus; while elaboration is defined as meaningfulness of the reaction. In the context of elaboration the level of detail of the drawing developing the original stimulus is also evaluated.

Respondents from the Czech Republic

To be able to evaluate originality, i.e. to decide whether the analysed solution was unusual, we needed solution categories that appeared regularly. We created these categories in the course of the first five years of the research (on the basis of about 300 pictures) using the pattern identification method. At present the categories may be said to be functional and allowing for inclusion of the newly created artefacts. Thus at present the method of simple listing provides more and more accurate information about frequency of the individual reactions of the respondents to the ambiguous stimulus provided to them (Table 1).

Table 1. List of categories and frequency-Czechia.

\begin{tabular}{|c|c|}
\hline Category & Frequency \\
\hline 1. Christmas tree & $50 \%-80 \%$ \\
\hline 2. Nature (a tree, a log, wood, a willow tree by a lake) & $12 \%-25 \%$ \\
\hline 3. Underwater world & $7 \%-15 \%$ \\
\hline 4. A figure & $1 \%-6 \%$ \\
\hline 5. An original solution (a piece of furniture, a fancy landscape, ...) & $0 \%-3 \%$ \\
\hline 6. An inadequate solution & $0 \%-1 \%$ \\
\hline
\end{tabular}


As mentioned above the categories are stabilised. The frequency of occurrence changes depending on the group characteristics and on the season of the year. The "Christmas tree" motif most depends on the season of the year. This solution has been most frequent in each group so far, occurring in about $20 \%$ of cases per group. In the periods of advent and after Christmas the occurrence rises to up to 80\%. The frequencies of occurrence in the above-mentioned table then show limit values of occurrence within which the solutions range. We only noted a single case, in June 2014, when the frequency of occurrence of certain categories changed significantly. Out of the total of 16 respondents $10(63 \%)$ chose the Christmas tree solution, which corresponded to the previous research results. But 4 (25\%) respondents chose the figure as the solution and only 2 (12\%) opted for the natural motif. The figure is one of the less frequent solutions and if it occurs at all then in maximum one case of the whole group.

There are big differences in elaboration in this group. There are respondents who put an overall concept to the picture and add details to it. Another group of the respondents complete the picture without creating an overall concept and further elaborating it. In these cases the number of details is lower. The most frequently scored component is overall concept and colour pattern, often accompanied by the fact that the picture is elaborated into a story (Table 2).

In the course of the final discussion $80 \%$ of the respondents mentioned that the Christmas tree occurred to them first, that they saw it in the picture immediately (as mentioned above the percentage of occurrence of the Christmas tree increased at Christmas time). About 30\% of the respondents said in this context that they did not want to accept the straightforward solution and continued with the search. If you apply the principle of the Torrance test to this situation, you can say that these $30 \%$ of the respondents did not let themselves be influenced by the first idea and sought another, more original solution. The remaining $20 \%$ replied that more possible solutions occurred to them and they chose the one they thought to be most original or easiest to depict. An interesting example is represented by the respondents using the task to create a fancy world or landscape. All of these respondents in accord said that they did not seek anything, they just started to complete the picture, relaxing in the process.

Inadequate solutions, i.e. lack of reaction of the respondent to the ambiguous stimulus, were rare and often hard to distinguish from the original solutions. In the case of controversial solutions we always looked for the overall concept of the picture, continuity of connection of the work of the respondent and the original picture section, framing of the original motif and answers of the respondents to their artefact.

After the close of the discussion the respondents were shown the whole picture, part of which they worked on. Most of them expressed surprise and liking for the figure in the original whole picture. In autumn 2011 a specific reaction appeared in one of the groups, when one respondent said that the solutions chosen by the respondents were not correct and thus the task was not accomplished. This was followed by definition of the notions of sign and symbol and a discussion over the factor that can affect perception of the sign or symbol.

Respondents from the People's Republic of China

Since 2010 we have had the chance to lecture periodically, always once a year, at the Sichuan Normal University at Chengdu in China for students of psychology and preschool pedagogy and for teachers working in special schools. The lectures focus on the options and limits of use of art therapy and artphiletic approach in children and youth with the need for a special approach to their education. Before the research commencement we applied other artphiletic and art therapeutic techniques as pilot research. On the basis of the pilot research results we arrived at the following facts:

Table 2. Artefact's mark rating and frequency—Czechia.

\begin{tabular}{cc}
\hline Detail Category & Frequency \\
\hline Colour pattern & $20 \%$ \\
Text (story) & $0 \%$ \\
Picture (story) & $5 \%$ \\
Merger of part of the picture with the art solution & $5 \%$ \\
Details & $10 \%$ \\
Overall concept & $50 \%$ \\
\hline
\end{tabular}


- The approach to the individual techniques (use of symbols) does not show any substantial cultural differences,

- Fundamental cultural differences appear in understanding the meaning of colours (red, yellow, white etc.),

- Further fundamental cultural differences appear in approach to the work and the subsequent reflection.

Explanations for the found differences needed to be sought in the creative profile, i.e. personality feature of Chinese students and their engagement in the research population. One of the answers can be found in the study results published by Cheung and Leung [13]. Their research population consisted of Chinese nursery school teachers. A fact very important for the general conclusions presented by us is that creativeness is considered an important feature of teachers in China preconditioning their work in the area of education and upbringing. The authors of the research looked for parameters of creativeness and arrived at five fundamental factors, namely cognitive ability, discipline, motivation, inventiveness and personal properties. Creativeness was also the subject of research performed by Wang and Greenwood [14], who compared reflection of creativeness by Chinese students in comparison to their perception of creativeness of Western students. One of the interesting results of that research essential for our work is the fact that Chinese students tend to underestimate themselves in this. With the increasing age of the students the level of self-underestimation decreased. Despite that, and in harmony with the results we arrived at, it can be concluded that creativeness of Chinese students must be provided with maximum support already from their school age. Creativeness of children from Tchai-Wan was studied by Mei-Hue and Dzeng [15]. More than a thousand children were categorised by age and cultural origin (city x village vs. immigrant mother). The conclusion relevant for the present research was that drawing skills developed with age but creativeness did not grow with the same speed and quality improvement.

These facts were also confirmed by our own research. The categories to which the produced artefacts could be included, partly corresponded to the categories defined on the basis of the works of respondents from the Czech Republic. Category change was again performed with the help of the pattern identification method (Table 3).

A fundamental difference was then found in use of details. In this group of respondents nearly all the pictures were filled up and showed a clear overall concept with a higher number of details; some of them had a story written into them and in other cases the story depicted by the picture was subsequently communicated orally (Table 4).

The higher number of details, the overall concept and addition of the story correspond to the way of work and presentation of work results which Chinese students are taught to apply.

Table 3. List of categories and frequency-China.

\begin{tabular}{llc}
\hline \multicolumn{1}{c}{ Category } & Frequency \\
\hline 1. & Nature (landscape, a tree) & $45 \%$ \\
2. & Underwater world & $35 \%$ \\
3. A boat & $15 \%$ \\
4. An original solution & $4 \%$ \\
5. & An inadequate solution & $1 \%$ \\
\hline
\end{tabular}

Table 4. Artefact's mark rating and frequency-China.

\begin{tabular}{cc}
\hline Detail Category & Frequency \\
\hline Colour pattern & $30 \%$ \\
Text (story) & $1 \%$ \\
Picture (story) & $85 \%$ \\
Merger of part of the picture with the art solution & $5 \%$ \\
Details & $80 \%$ \\
Overall concept & $85 \%$ \\
\hline
\end{tabular}




\subsection{Comparison of Results}

In the Czech Republic the Christmas tree was the most frequently occurring reaction to the picture section presented. Due to the cultural differences this motif did not appear in the reactions of the Chinese respondents at all, or, more accurately speaking, it appeared only once in the form of a "Christmas branch" in a vase on the table. This case allows for the conclusion that the absence of the Christmas tree category in China, most frequently occurring in the Czech Republic, was conditioned by cultural differences between the two nations.

Another motif was nature, or most frequently: A tree, nature, a landscape. Both groups more frequently than not included in the picture a substrate for grass, water and also for the tree. The motif of a tree appeared in both groups and its depiction was similar in the two groups of respondents: A willow tree or a tall deciduous tree. In Group 1 another frequent motif in this context was also a log or just wood-a cut down tree.

An interesting group of motifs was the underwater world. Some pictures were very similar (see Figure 2 and Figure 3) and no cultural differences were manifested at first sight.

However, in Group 2 the pictures of this category included more details, a higher level of elaboration and more cases of connection with a story. Group 2 used the motif of a boat, which was never noticed in Group 1 throughout the research period.

About 1\% - 6\% of respondents of Group 1 presented a human figure or a face of a being. This solution never appeared in Group 2. Even when confronted with possible solutions used by the Czech respondents the respondents from China said that they would never think of a similar solution to the task themselves.

The last group was then represented by original solutions. These solutions were rare and the participants using them took a longer time to create them or connected a story with them. These solutions were equally rare in both groups.

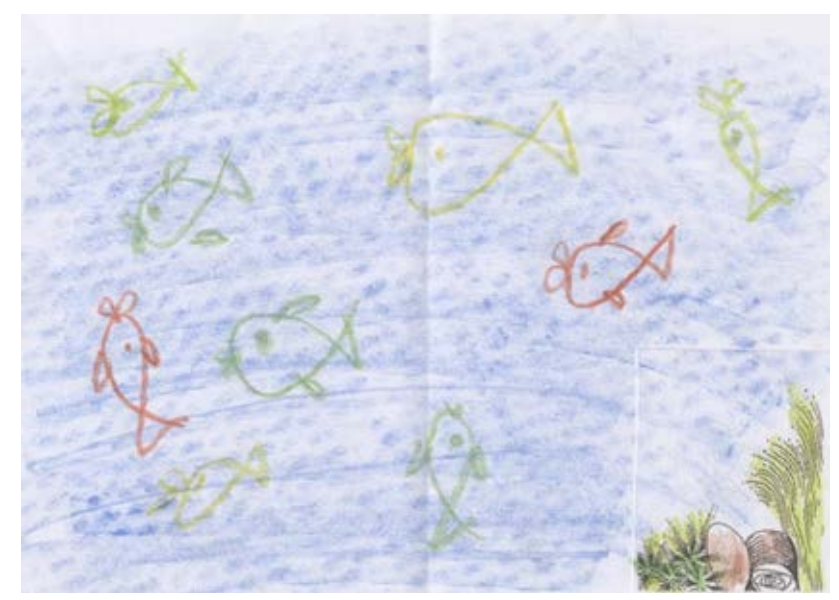

Figure 2. Submarine world-Czechia.

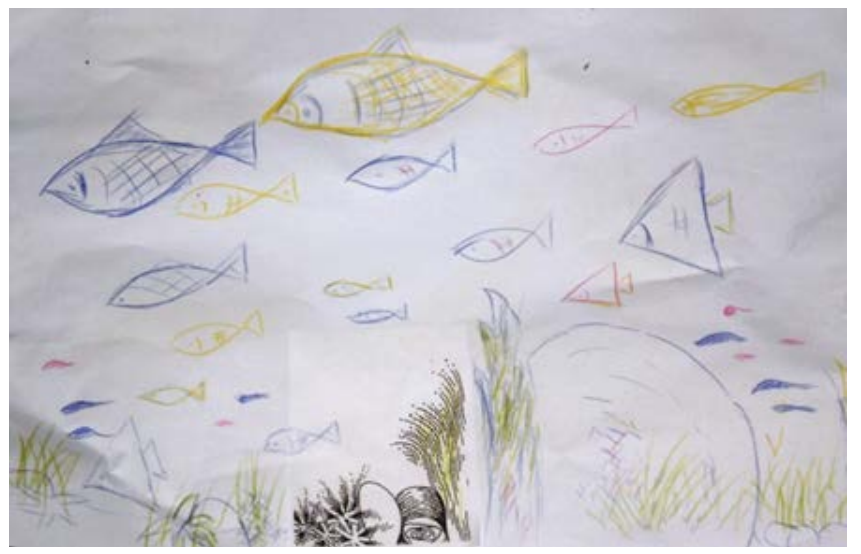

Figure 3. Submarine world-China. 


\section{Conclusions}

In the case of the respondents from the Czech Republic the most frequently used solution was the Christmas tree. In harmony with the principles of the Torrance figural test of creative thinking this solution cannot be defined as original. The respondents using this solution used the first idea that occurred to them and did not continue seeking. Leaving aside this motif, which for obvious cultural reasons did not occur in Group 2, both groups equally frequently and with very similar appearance used the motif of nature and underwater world. In harmony with the theoretical background of the Torrance Figural Test of Creative Thinking these approaches can be considered more original than the Christmas tree motif. In the subsequent discussion most respondents mentioned that this solution occurred to them as the second after the Christmas tree. Due to the frequency of occurrence even these solutions cannot be considered too original. The motif of the boat might be taken as an original solution in the context of comparison of both groups. But as in Group 2 this motif appeared quite frequently it again cannot be considered too original in the sole context of this group.

Truly original motifs included the human body or face used by respondents of Group 1 and the individual solutions appearing only once in either group and grouped under the common label “Original Solutions”.

Focusing on originality of the solutions, i.e. the level of creativeness, the presence of stereotypes must probably also be taken into consideration. When attempting to explain the data obtained by the abovementioned research we came across a certain burden affecting the students and probably carried over from the previous stages of education. Perception and stereotypes, albeit in another context, are mentioned by Baxter and Kavanagh [16], who describe the burden of stereotype as a substantial obstacle in preparation of university students.

The purpose of this research was to find out whether there are cultural differences in reactions of the respondents to an ambiguous stimulus and what they are, if any. Application of the method of reconstruction resulted in both groups in motifs that can be said to be affected by the cultural background of the respondents as well as in motifs that can be classified as supra-national. Cultural differences in perception of aesthetic stimuli, if known, can help develop creativeness of students, teachers and, subsequently, their pupils. A study on this theme was published by Karkou et al. [17]. They monitored groups from Great Britain, Russia and Latvia. Cultural differences reflect not only in perception of artefacts and further therapeutic work but also in preparation of therapists as far as form and orientation are concerned. This study also clearly emphasises the effect of historic development of the society on basic concepts of therapies, art therapy inclusive. This may be assumed to lay foundations for a wider concept of perception, thinking and creativeness in other areas of human activity. This experience is mentioned by Kay [18] in relation to his own research. The presented results clearly support inclusion of activities supporting development of creative thinking in the form of art therapeutic or artphiletic techniques into work with pupils and students at school. Similarly in the Czech environment Trna and Trnová [19] say that regarding their own research it is necessary to have developed creativeness as a personality feature of teachers penetrate their work, in this case represented by teaching of natural science subjects. This is very closely related to what Allison [20] describes as a significant benefit of practical cooperation of art therapists and teachers, who as a consequence include in their teaching methods elements or procedures learned in the context of their art therapy studies. Differences based on language culture and specific features of reality processing by representatives of groups with different cultural background are mentioned among the research results published by Lenz [21]. Out of what he emphasises the closest connection with our theme is represented by the necessity of a very careful selection of techniques not only of approach to pupils or clients but also to the supervision provided to the therapists themselves mentioned by him. All of the above-mentioned parameters should be considered in both of these views. Another aspect is creativeness as a general feature of representatives of any culture. In relation to our research, the results of a study by Huang [22], who focused on creativeness as an assumption of problem solving in the case of Chinese students in a foreign (English) environment, can also be used. Creativeness, self-concept and ability to react quickly were areas in which the author of this research saw room for improvement in the monitored students. The same theme was also addressed for example by Pretz and McCollum [23]. These authors showed in a sample of university students that there is not any direct relation between the actual level of creativeness and self-concept in the same area; explaining this fact by effect of personality structure. The impact of cultural differences on preparing university students presents Öbrink Hobzová [24].

Let us conclude by saying that all reactions to ambiguous stimulus described in professional literature on this theme appeared in both studied groups: Acceptance of the first idea, rejection of the first idea and a search for another, original solution, as well as fear of non-fulfilment of the task. Both groups also showed normal frequency 
structure of original, non-adequate and standard solutions. Students from the Czech Republic applied a lower level of detail in their approach to the task solution in comparison to the students from China. A fundamental difference could be seen in the actual presentation of the created solution. Students form China tended to present their solution very clearly and unambiguously, expecting a clear answer regarding whether their solution was correct or not.

\section{Acknowledgements}

This research was supported by the grant UPOL CMTF_2014_017 SPP 436100107.

\section{References}

[1] Plháková, A. (2003) Učebnice obecné psychologie. Academia, Praha.

[2] Carter, P.J. and Russell, K.A. (2002) Trénink paměti a kreativity: Př́́klady s řešením. Computer Press, Praha.

[3] Smékal, V. (2004) Pozvání do psychologie osobnosti: Člověk v zrcadle vědomí a jednání. Barrister \& Principal, Brno.

[4] Žák, P. (2004) Kreativita a její rozvoj. 1. vyd. Computer Press, Brno.

[5] Schum, N., Franz, V., Jovanovic, B. and Schwarzer, G. (2012) Object Processing in Visual Perception and Action in Children and Adults. Journal Of Experimental Child Psychology, 112, 161-177. http://dx.doi.org/10.1016/j.jecp.2012.02.008

[6] Liebmann, M. (2005) Skupinová arteterapie Nápady, témata a cvičení pro skupinovou výtvarnou práci. Portál, Praha.

[7] Slavík, J. (1997) Od výrazu k dialogu ve výchově-Artefiletika. Habilitační práce. Karolinum, Praha.

[8] Albert, R. (2010) Being Both: An Integrated Model of Art Therapy and Alternative Art Education. Art Therapy: Journal of the American Art Therapy Association, 27, 90-95. http://dx.doi.org/10.1080/07421656.2010.10129713

[9] Nelson, C. (2010) Meeting the Needs of Urban Students: Creative Arts Therapy in Jersey City Public Schools. Art Therapy: Journal of the American Art Therapy Association, 27, 62-68. http://dx.doi.org/10.1080/07421656.2010.10129711

[10] Pospíšilová, H. (2013) Výchovné cíle a metody v práci sociálního pedagoga. In: Potměšilová, P. a kol. Sociální pedagogika v teorii a praxi. UP, Olomouc.

[11] Potměšilová, P. (2012) Metoda rekonstrukce v kulturním kontextu. Arteterapie: Časopis České arteterapeutické asociace se zaměrením na arteterapii, artefiletiku, muzikoterapii a dramaterapii, 29, 13-21.

[12] Potměšilová, P. (2014) Arteterapie. In: Müller, Oldřich a kol. Terapie ve speciální pedagogice. 2. přeprac. vyd. Grada, Praha, 77-131.

[13] Cheung, R. and Leung, C. (2014) Preschool Teachers' Perceptions of Creative Personality Important for Fostering Creativity: Hong Kong Perspective. Thinking Skills and Creativity, 12, 78-89. http://dx.doi.org/10.1016/j.tsc.2014.01.001

[14] Wang, B. and Greenwood, K. (2013) Chinese Students' Perceptions of Their Creativity and Their Perceptions of Western Students' Creativity. Educational Psychology, 33, 628-643. http://dx.doi.org/10.1080/01443410.2013.826345

[15] Mei-Hue, W. and Dzeng, A. (2013) Cultural and Age Differences of Three Groups of Taiwanese Young Children’s Creativity and Drawing. Psychological Reports, 112, 900-912. http://dx.doi.org/10.2466/21.04.PR0.112.3.900-912

[16] Mei-Hue, W. and Dzeng, A. (2013) Cultural and Age Differences of Three Groups of Taiwanese Young Children’s Creativity and Drawing. Psychological Reports, 112, 900-912.

[17] Karkou, V., Martinsone, K., Nazarova, N. and Vaverniece, I. (2011) Art Therapy in the Postmodern World: Findings from a Comparative Study across the UK, Russia and Latvia. The Arts in Psychotherapy, 38, 86-95. http://dx.doi.org/10.1016/j.aip.2010.12.005

[18] Kay, L. (2013) Bead Collage: An Arts-Based Research Method. International Journal of Education \& the Arts, 14, $1-18$.

[19] Trnova, E. and Trna, J. (2014) Implementation of Creativity in Science Teacher Training. International Journal on New Trends in Education \& Their Implications (IJONTE), 5, 54.

[20] Allison, A. (2013) Old Friends, Bookends: Art Educators and Art Therapists. Art Therapy: Journal of the American Art Therapy Association, 30, 86-89. http://dx.doi.org/10.1080/07421656.2013.787215

[21] Lenz, A.S. (2014) Integrating Relational-Cultural Theory Concepts into Supervision. Journal of Creativity in Mental Health, 9, 3-18. http://dx.doi.org/10.1080/15401383.2013.864960

[22] Huang, R. (2005) Chinese International Students Perceptions of the Problem-Based Learning Experience. Journal of Hospitality, Leisure, Sport \& Tourism Education, 4, 36-43. http://dx.doi.org/10.3794/johlste.42.108

[23] Pretz, J. and McCollum, V. (2014) Self-Perceptions of Creativity Do Not Always Reflect Actual Creative Performance. 
Psychology of Aesthetics, Creativity, and the Arts, 8, 227-236. http://dx.doi.org/10.1037/a0035597

[24] Öbrink Hobzová, M. (2011) Srovnání učebnic pro imigranty v České republice a ve Švédsku. In: Metody a formy práce ve výuce mateřského jazyka. Sborník z mezinárodní konference ze dne 6. dubna 2010. HANEX, Olomouc. 